(200)

Unzeo

\title{
An Evaluation of the use of Drillers' Logs in Lithologic Studies of the Ogallala Formation of the Southern High Plains of Texas
}

By C.A.Wilson, J.T. Smith. G.L.Thompson and W.M.Sandeen

U.S. GEOLOGICAL SURVEY

WATER RESOURCES DIVISION

Prepared by the U.S. Geological Survey in cooperation with the Texas Water Development Board

$$
\text { June } 1972
$$

72.451 
CONTENTS

Page

Abstract-1.

Introduction-

Purpose and scope of the project-1. 2

Location and extent of the area-1... 2

Methods of investigation-

Availability of data- 4

Computer analysis of drillers' logs and other hydrologic data-

Test-hole drilling- 12

Geophysical logging-_- 16

Methods of measuring hydraulic conductivity-_... 22

Results of the investigation- 25

Utility of drillers' logs- 25

Utility of computer analysis of drillers' logs

Reference cited-1 35 


\section{TABLES}

Table 1. Availability of water-well drillers' logs in counties where data were prepared for computer analyses-1. 6

2. Lithologic lexicon of the Ogallala Formation-.......- 11

3. Summary of geophysical logging of wells in the

Ogallala Formation-_. 21 
AN EVALUATION OF THE USE OF DRILLERS' LOGS

IN LITHOLOGIC STUDIES OF THE

OGALLALA FORMATION OF THE

SOUTHERN HIGH PLAINS OF TEXAS

PROGRESS REPORT 1970-71

By

C. A. Wilson, J. T. Smith, G. L. Thompson, and $W$. M. Sandeen

U.S. Geological Survey

\begin{abstract}
Logs made by water-well drillers were analyzed in conjunction with test-hole drilling and geophysical logging to evaluate usefulness of the driller's $\log$ in delineating areas that would be suitable for artificial recharge of the Ogallala Formation. This preliminary study indicates that lack of detailed and accurate information in many drillers' logs prevents their use as a reliable source of lithologic information. For many applications, such as evaluation of potential areas for artificial recharge, the value of more complete and more accurate information will be readily apparent as these applications become more widespread. More effort will be required in collecting lithologic information as part of the drilling operations.
\end{abstract}




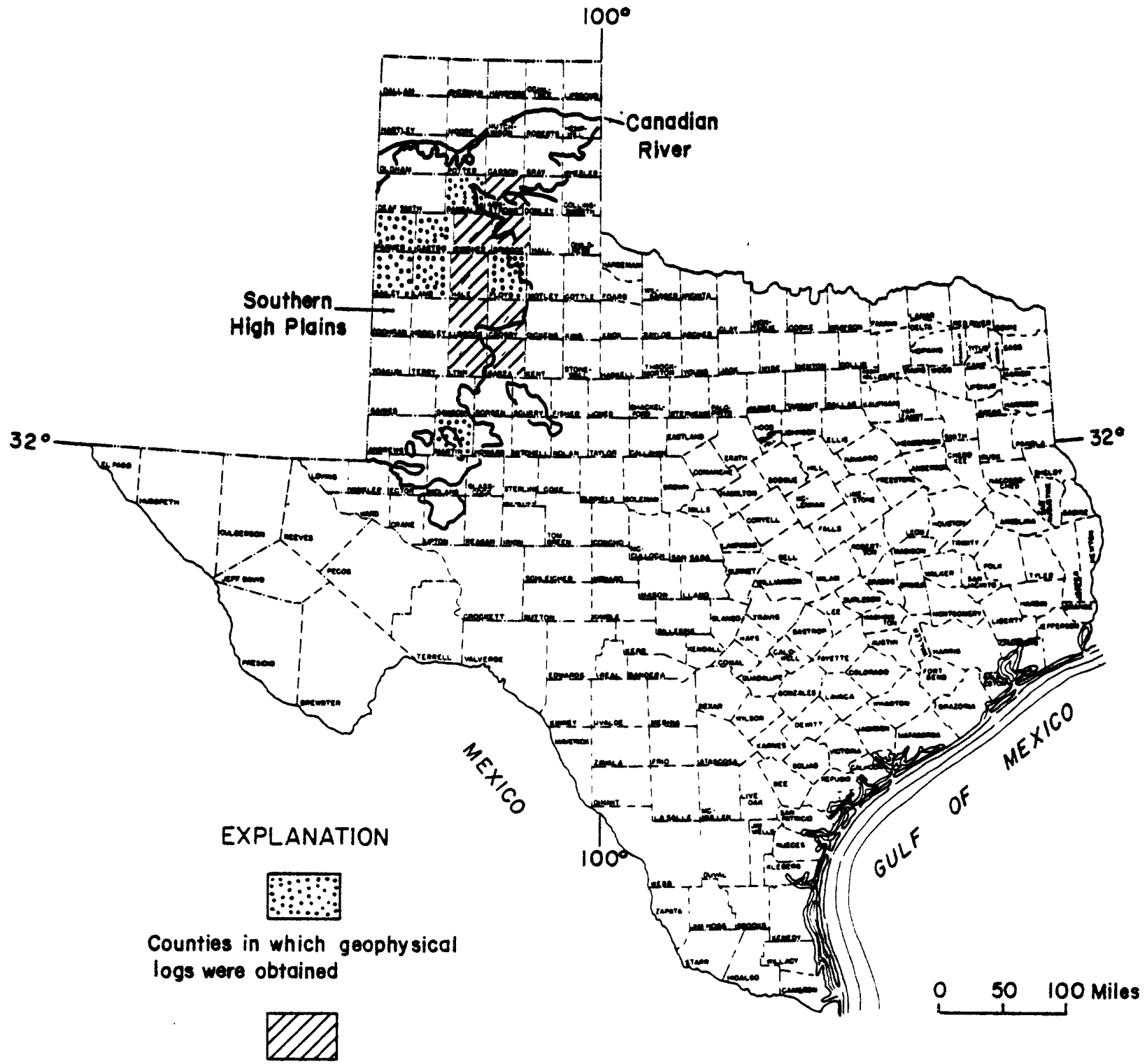

Counties in which geophysical logs and drillers' logs were obtained

FIGURE I.-Location of the study area and counties in which data were collected 
Values given on drillers' logs such as water levels, are accurate; but information on quantitative values such as well yields and drawdowns, which were estimated or which are given as representative, may contain gross errors. Many well locations, especially those given on application forms for well permits or on well-data reports, are of questionable accuracy. A greater degree of accuracy in determining well-site elevations is now possible through the use of $71 / 2$ - and 15-minute Geological Survey topographic maps.

Table 1 shows the availability of drillers' logs in counties where the data were prepared for computer analysis. These logs were screened to eliminate those that: (1) Did not show the base of the Ogallala;

(2) could not be located to an estimated accuracy of 1 mile on $71 / 2$ - or 15-minute topographic maps; or (3) did not have a continuous sequence of lithology. Locations for most of the logs selected for computer analys is are accurate to within $1 / 4 \mathrm{mile}$.

More logs were available in Lubbock County and in the northern onefifth of Lynn County because these areas are within the boundaries of the High Plains Underground Water Conservation District No. 1. The District requires that a driller's $\log$ and well-construction data be filed upon completion of each well. 


\section{METHODS OF INVESTIGATION}

\section{Availability of Data}

Drillers' logs of water wells are sources of extensive data on the lithology and structure of the Ogallala Formation of the Southern High Plains; in 1969, there were about 59,000 irrigation wells in the area. Most of the logs are in the files of the Texas Water Development Board, the High Plains Underground Water Conservation District No. 1, and the U.S. Geological Survey. Other, but less extensive data include well schedules, water-level measurements, drawdown-yield measurements, pumpage inventories, well-location maps, results of aquifer tests, and water-quality analyses. Very little of the data in the Geological Survey files have been. gathered since 1958. Data in the files of the Texas Water Development Board date mostly from 1964 to 1971; the most recent material is the most abundant. Some geophysical logs may be available from oil-company files.

A limited amount of geologic data and water-quality analyses are available from the Geology Departments of Texas Tech and Texas A\&M Universities. Some field data and ground-water depletion surveys are available from the files of consulting geologists and engineers who have worked in the area. Wellconstruction data are available from the records of water-well drilling contractors. 


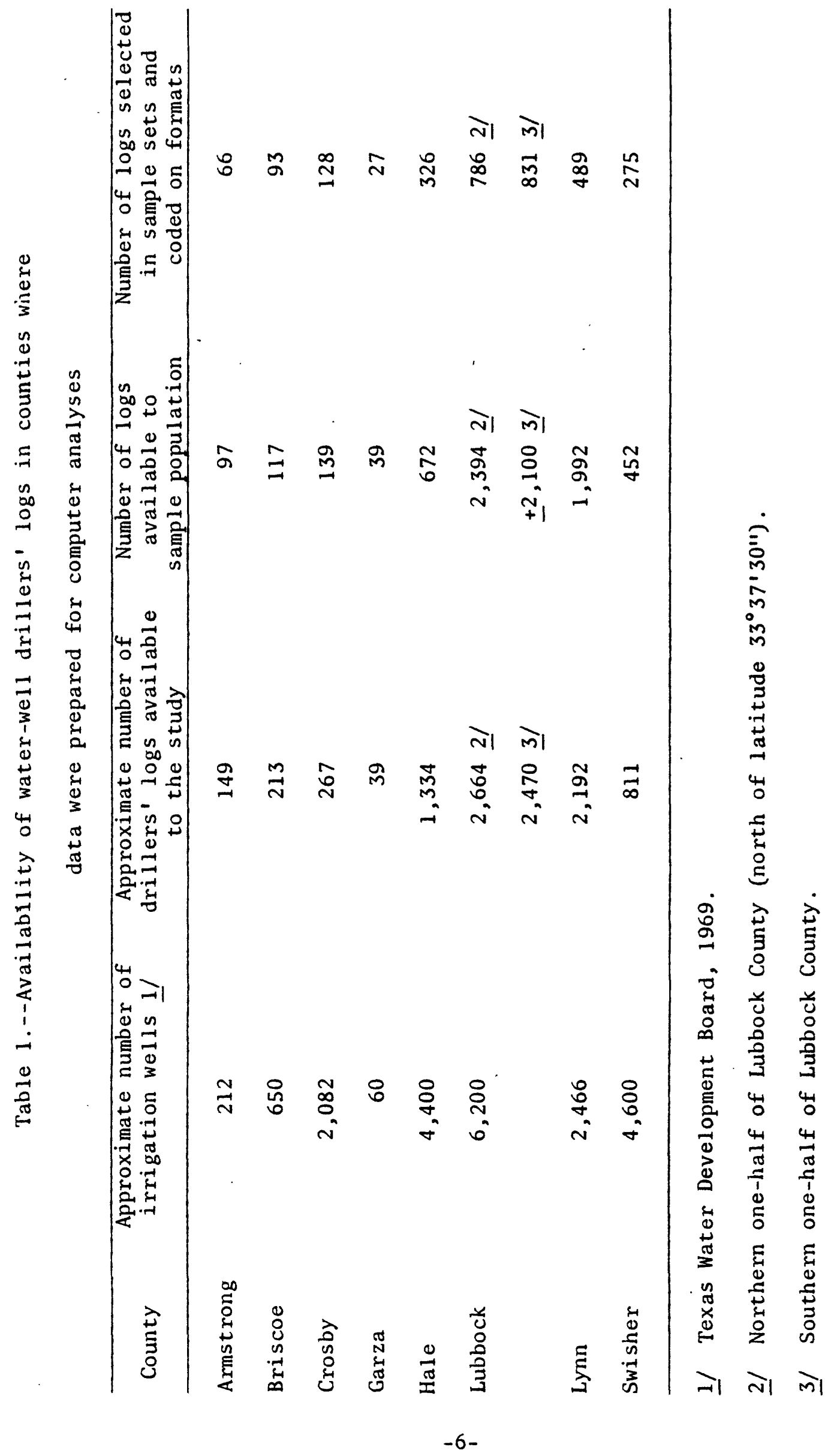




\section{Computer Analysis of Drillers' Logs and Other Hydrologic Data}

The formats developed for coding drillers' logs and other geologic and hydrologic data are shown on figures $2 a$ and $2 b$. The lithologic lexicon for the Ogallala Formation is given in table 2.

The procedures used in manual processing of drillers' logs for coding are illustrated by the systems flowchart shown on figure 3 . The coded formats were mailed to the New Mexico District for conversion into punched cards for computer input.

A sample of the available logs were used for an initial evaluation of the usefulness of drillers' logs. Sample set No. I consists of one log per 2 1/2-minute quadrangle, and set No. 2 consists of two logs per $21 / 2$ minute quadrangle, or 25 percent of all logs in the quadrangle, whichever is greater. Not all quadrangles, however, will have enough logs (minimum of three) for a complete sample selection.

The purpose of the second set was to compare the results based on the greater sampling with that obtained from the first set. If the results were not comparable, successive samplings would be tried to see if a suitable match was obtained. 


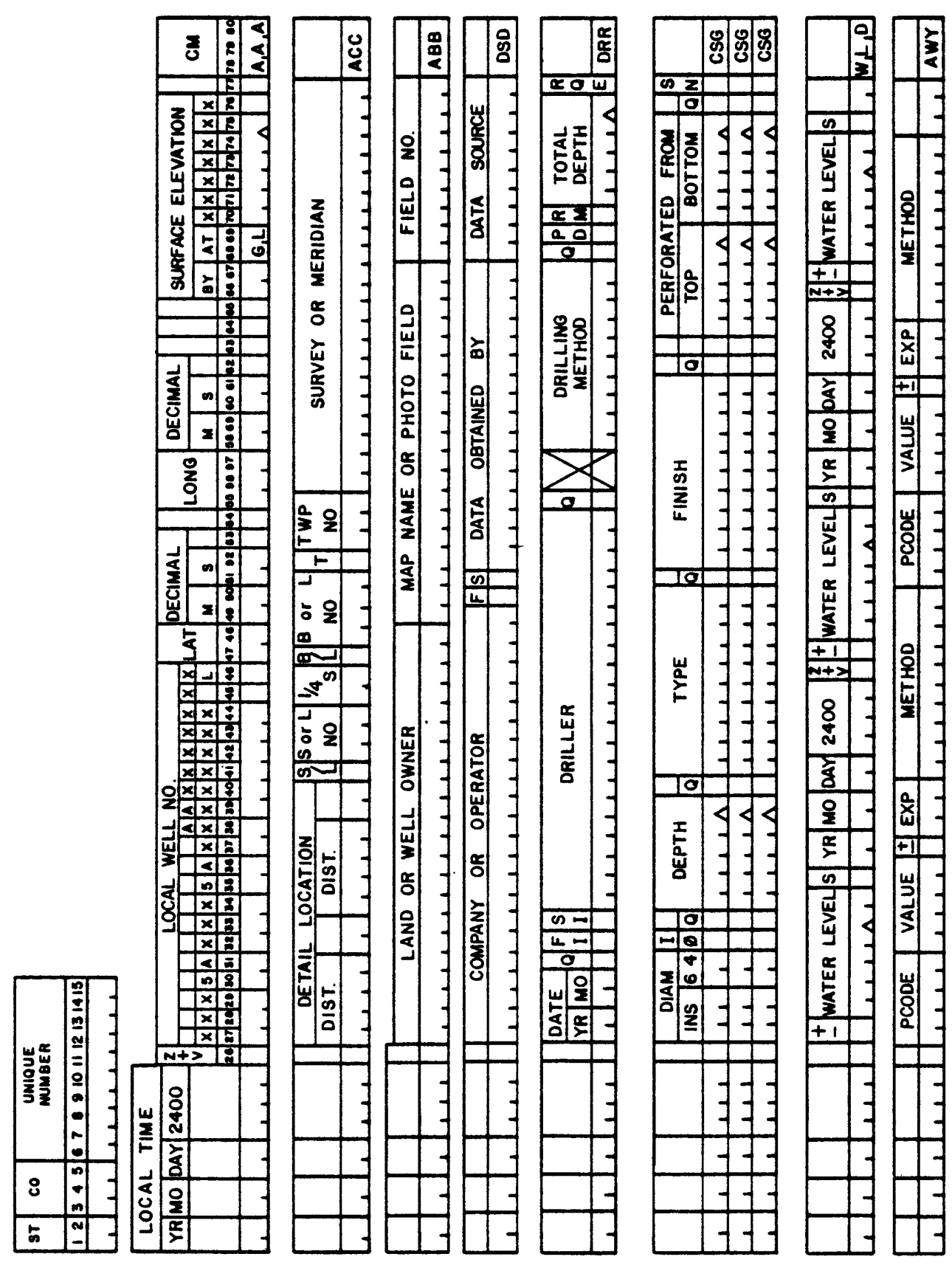




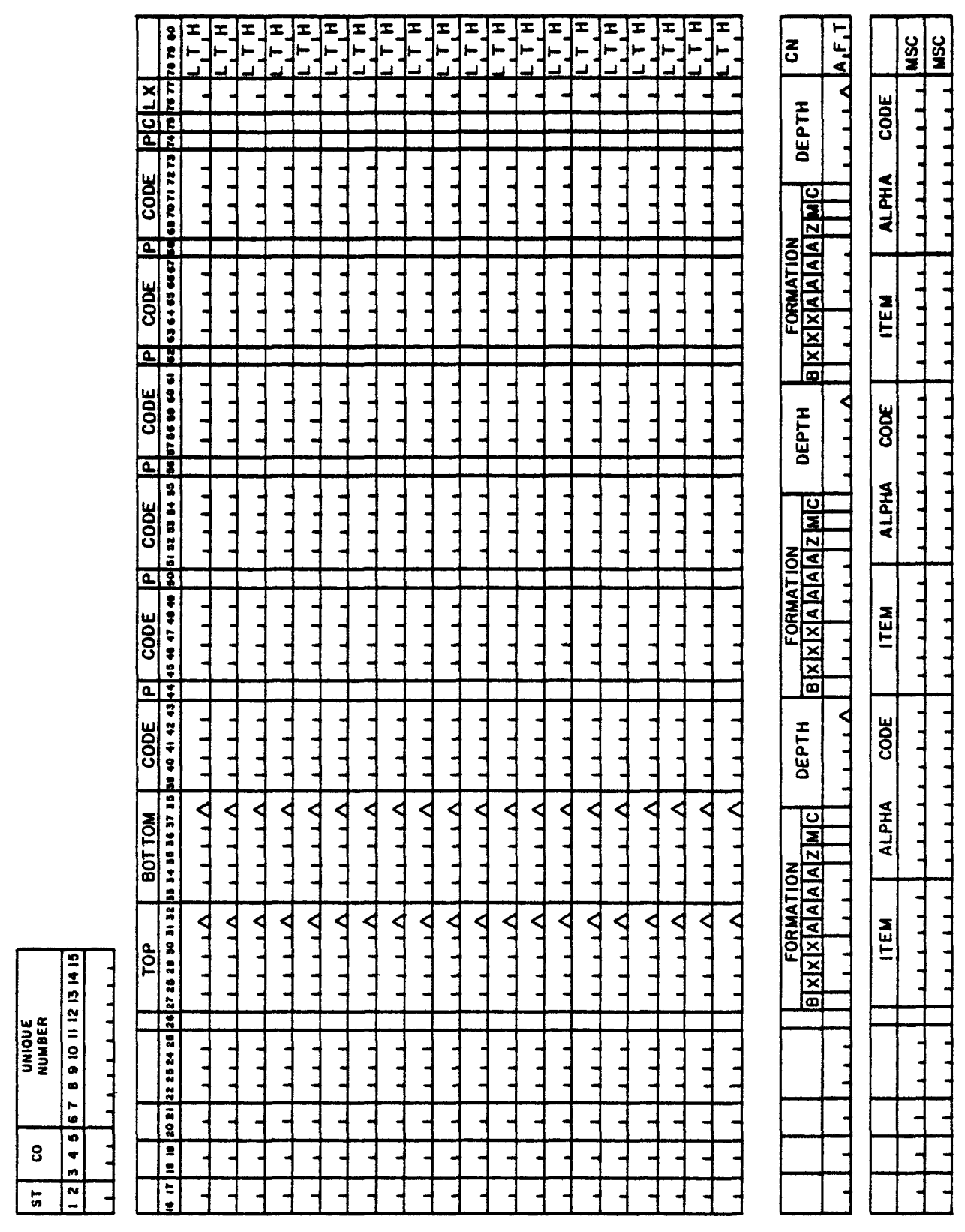

o 


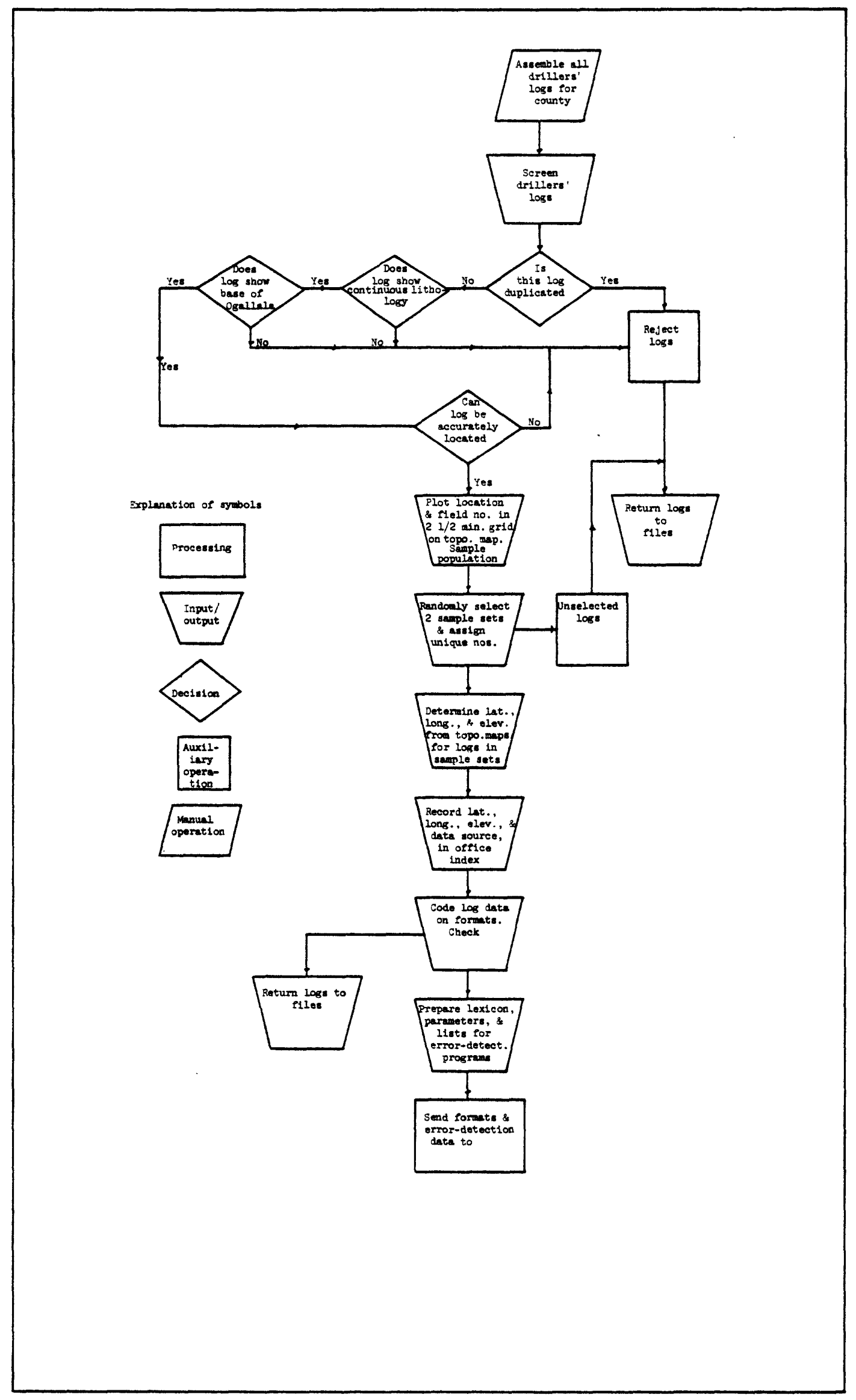

Figure 3. Flowchart for manual processing of drillers' logs 


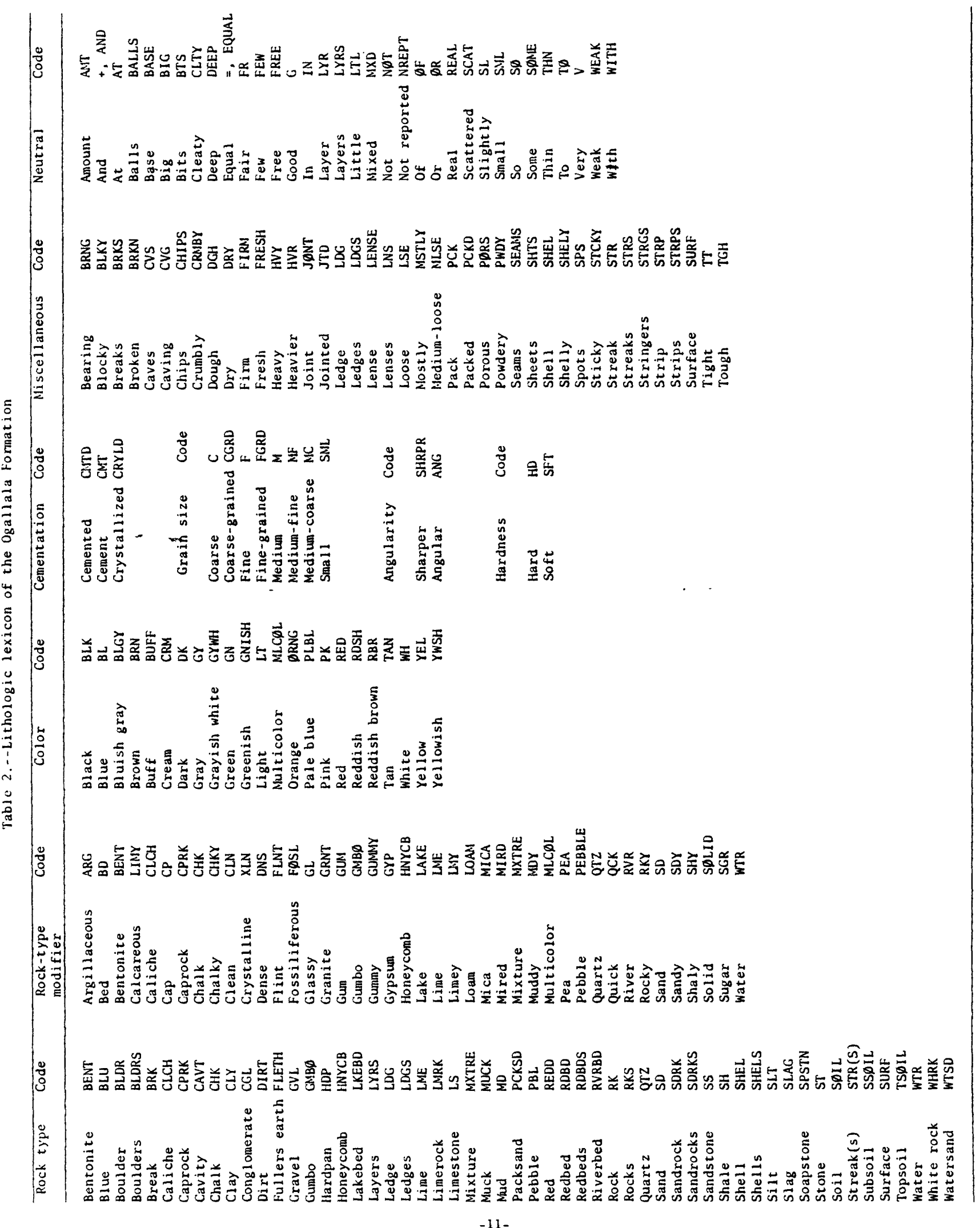


The general processing systems used by the New Mexico District are shown on figures 4, 5, and 6. After a series of error checks, updating, sorting, and merging, all coded data for each county are stored on magnetic tape. The computer output is obtained by using a program that lists the desired terms from the Ogallala lithologic lexicon (table 2) or terms used in the New Mexico District data file (OMNIANA). The requested information is retrieved from storage by the computer and can be converted into a variety of data output such as coordinate points, value plots, tables, graphs, or visual displays.

This study is primarily concerned with an output series of contour maps based on lithologic or structural data. Coordinate points, based on latitude and longtitude, are plotted by an off-line plotting device. The desired values are printed adjacent to the coordinate point, and these values may then be contoured by hand. The values could be contoured by machine if the computer were programmed for this operation.

\section{Test-Hole Drilling}

During fiscal year 1971, 58 test holes (total footage of 5,617 feet) were completed in 80 days of auger drilling in Briscoe, Hale, and Swisher Counties. The drilling unit, which was provided by the U.S. Geological Survey from Denver, Colorado, is equipped with 5 -foot sections of a 5 3/4inch diameter hollow-stem auger. The unit is also equipped with a splitspoon sampling device for taking undisturbed formation samples for laboratory analysis. 


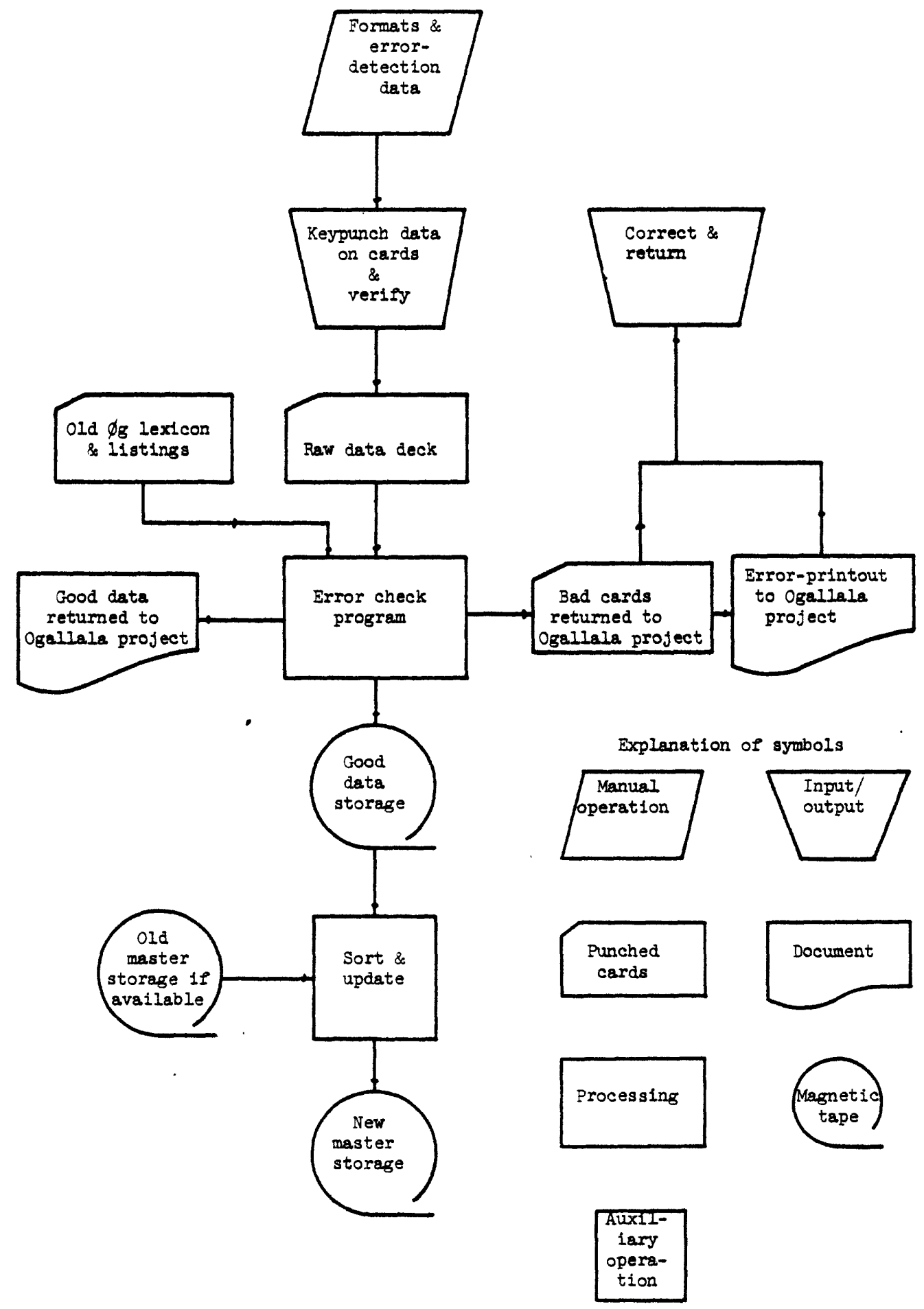

Figure 4. Systems flowchart for processing coded formats 


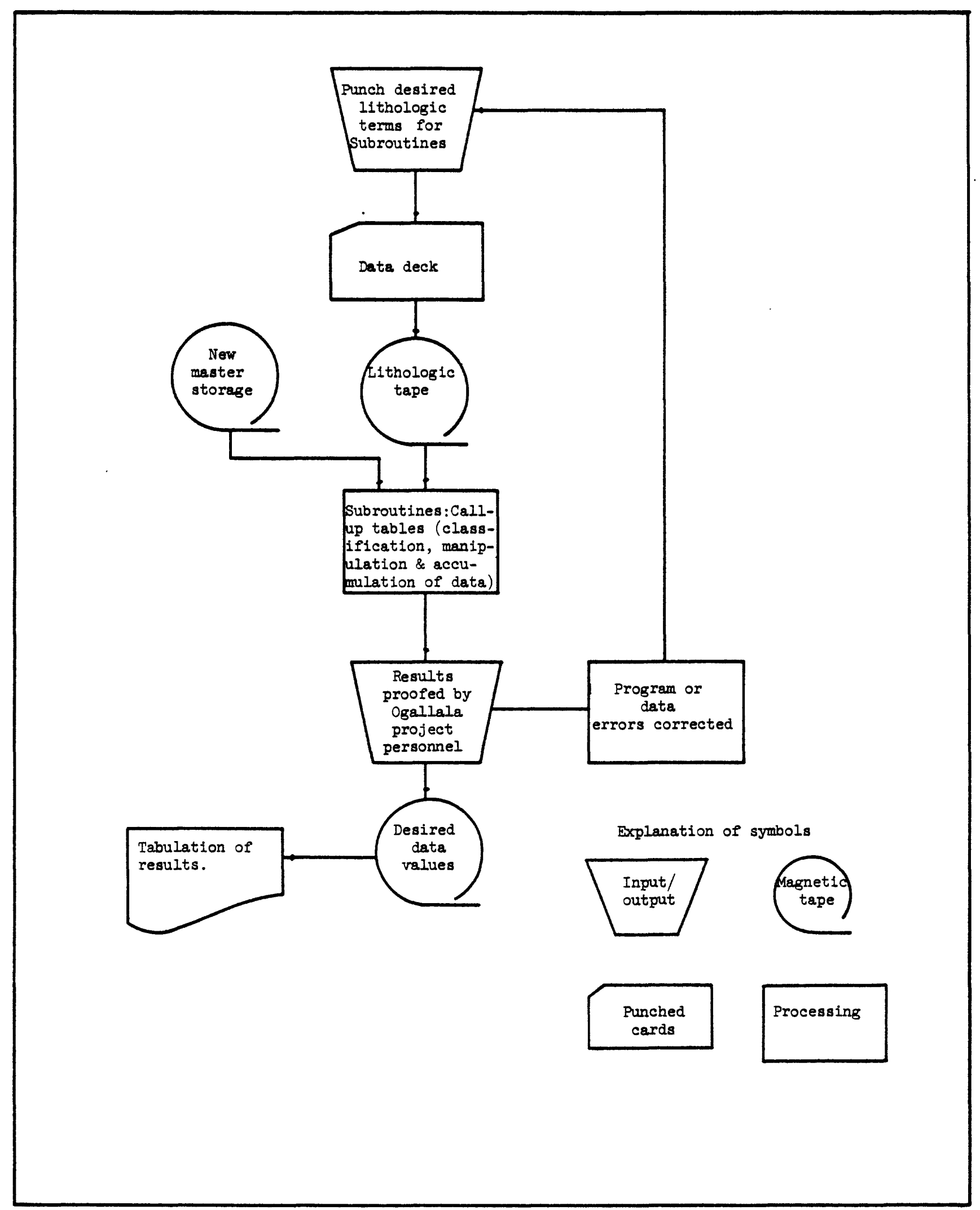

Figure 5. Systems flowchart for table-generating programs 


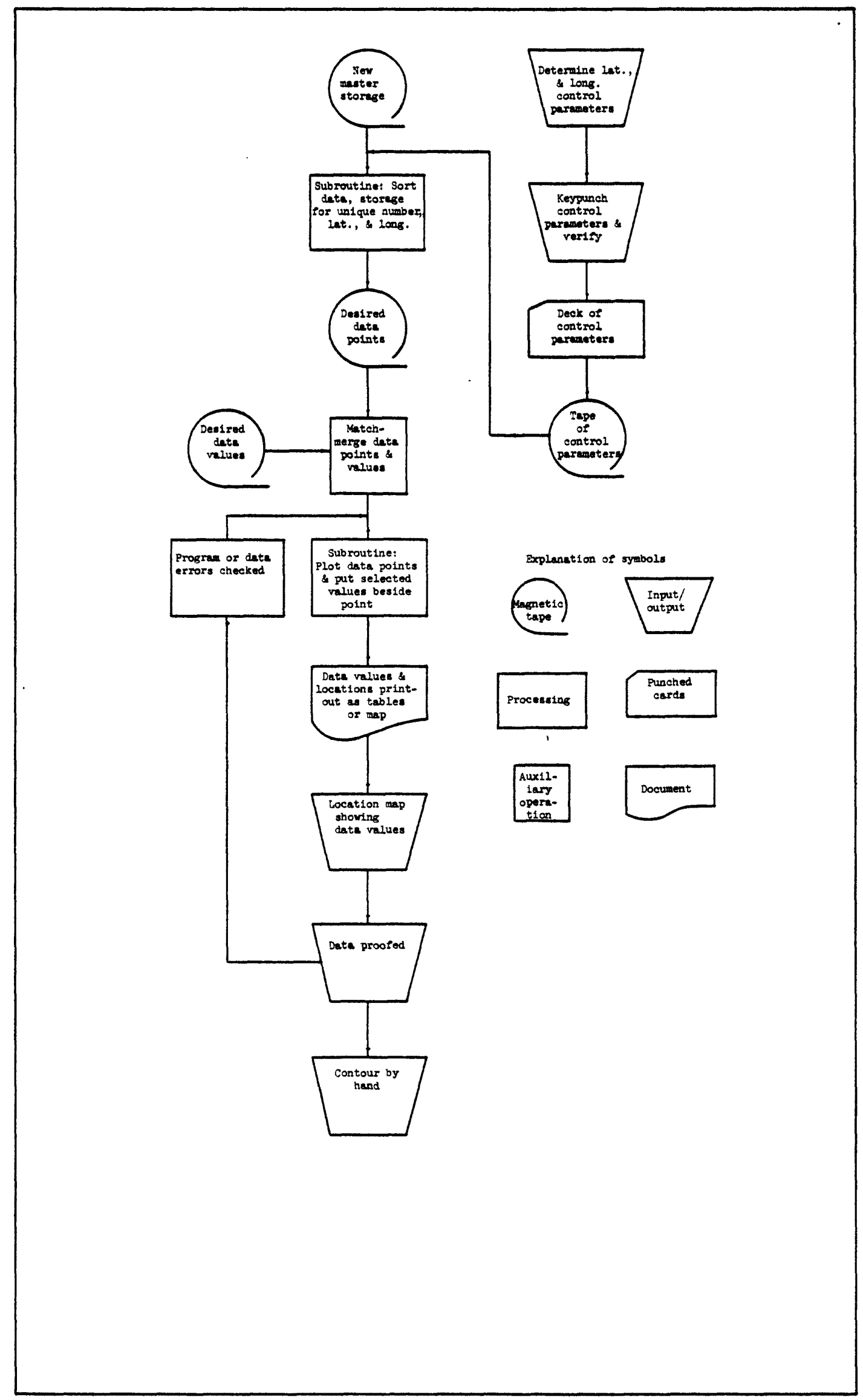

Figure 6. Systems flowehart for plotting data positions and values 
Two test holes, one deep (100 to 150 feet) and one shallow (40 to 50 feet) were drilled at most sites. First the deeper hole was drilled, logged, and sampled at 5-foot intervals or at changes in lithology. After the hole was completed, a gamma-ray log was made through the hollow-stem auger, and then the auger was removed. Another gamma-ray log was made in the uncased hole. In addition, electrical and caliper logs were made at some sites, and some undisturbed samples were taken at the bottom of the holes. All of the data acquired by these operations were used to construct a lithologic $\log$ of the test hole.

The second, shallower hole was usually drilled about 10 feet or less from the first hole and was bottomed in a relatively impermeable layer of clay or silt. The desired depth was determined from analysis of the logs of the deeper hole, and an undisturbed sample was taken with the split-spoon sampler to determine the hydraulic conductivity.

\section{Geophysical Logging}

Geophysical well logs, including gamma-ray, electrical, caliper, and temperature, were used mainly to identify and to determine the boundaries of various lithologic units penetrated by the well. Some additional data on water quality, water temperature, and sediment consolidation can be obtained from the logs. 
A total of 309 logs was made in 222 wells and test holes during fiscal years 1970 and 1971. Gamna-ray logs were made in all test holes and wells. Electrical logs were made in some uncased wells and other types of logs were made in a few selected wells and test holes. Table 3 gives the number and types of logs made in the various counties of the study area.

A comparison of the lithologic $\log$ and the gamma-ray $\log$ for test hole AK-11-12-8A is shown on figure 7. On completion of drilling a test hole, it is best to make a gamma-ray $10 \mathrm{~g}$ through the hollow-stem auger or drill stem because caving of the hole may occur when the drilling tools are removed. A second gamma-ray $\log$ is made after the auger or drill stem is removed. Casing, auger, and drill stem all tend to subdue the response received by the logging instruments. The difference in the character of the gamma-ray $10 \mathrm{~g}$ made through the hollow-stem auger and in the same hole after the auger was removed is shown on figure 8 .

The effect of logging through the casing of a large-diameter well is shown by the gamma-ray $\log$ of wel1 XT-11-20-5A (fig. 8), located about 800 feet east of well XT-11-20-5B. Logging below the water table increases the loss of response in addition to the loss caused by the casing. Gamma-ray logs made in gravel-packed or cemented wells are not accurate because the measured radioactivity is caused by both the sediments and the gravel pack or cement. Figure 9 shows a comparison of gamma-ray logs in well SP-24-32-8A made first in the open test hole and then after the well was reamed out, cased, gravel-packed, and cemented. 
AK 11-12-8A

Armstrong County

$34^{\circ} 46^{\prime} 26^{\prime \prime} \mathrm{N} 101^{\circ} 32^{\prime} 51^{\prime \prime}$

Elov. 3412 feet

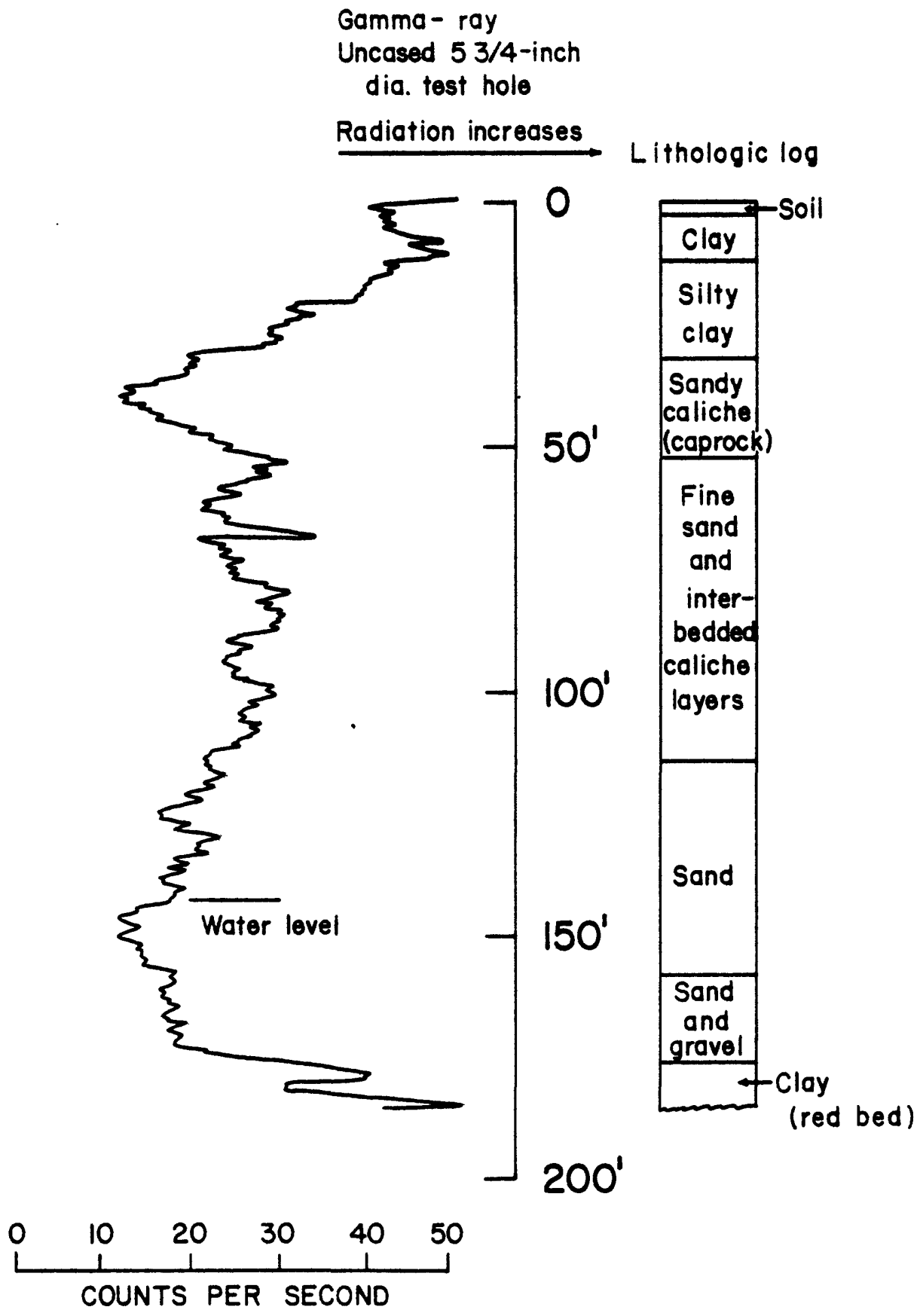

FIGURE 7.-Gamma-ray log and lithologic log of test-hole AK II-12-8A in Armstrong County 

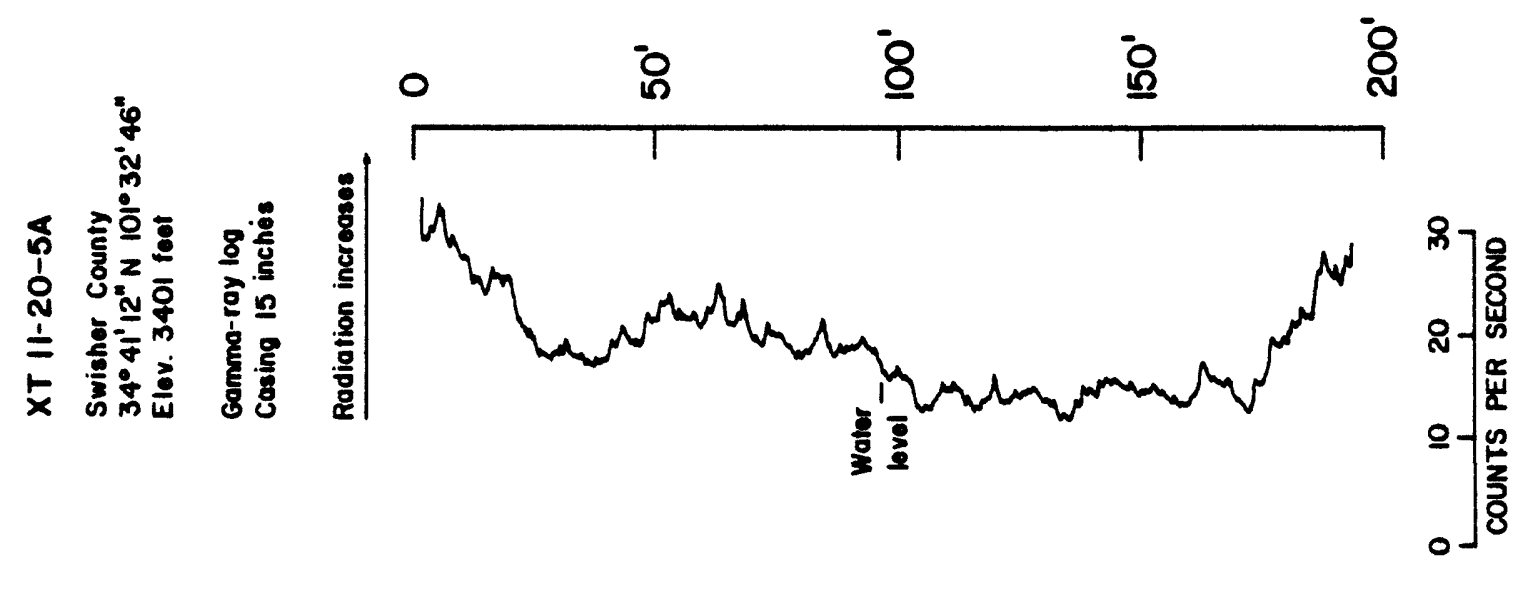

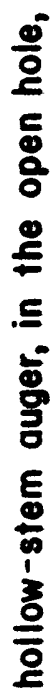

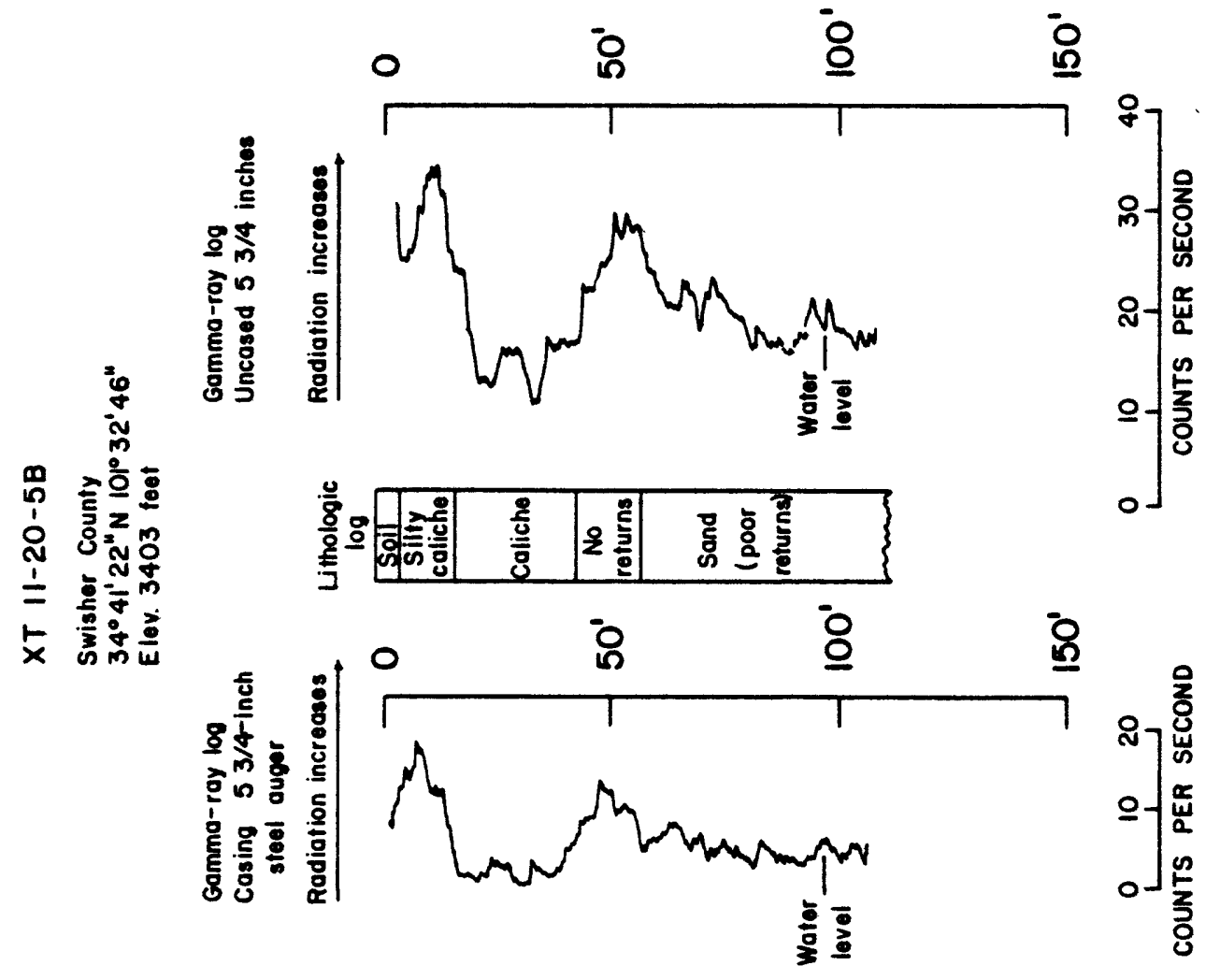



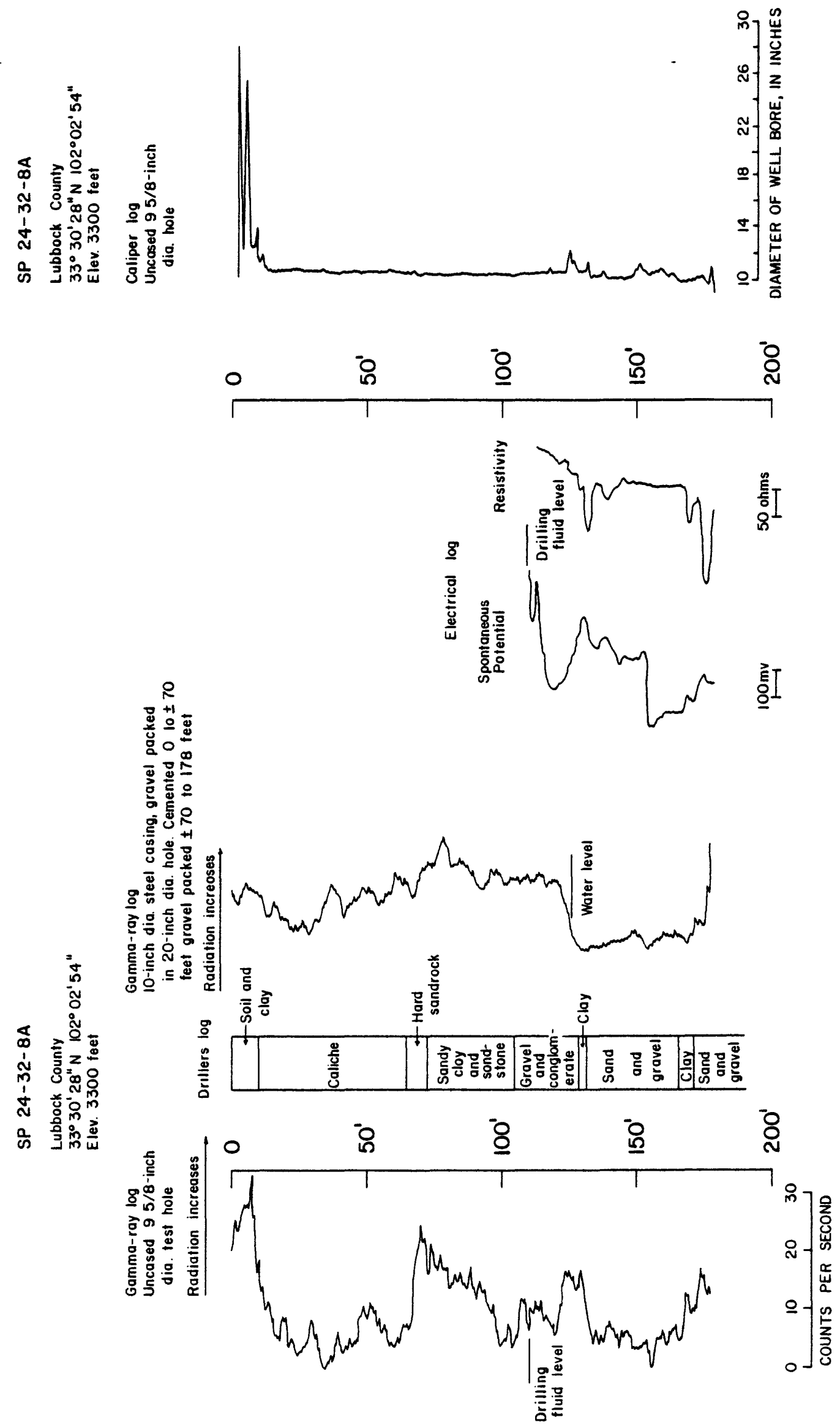

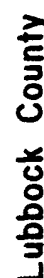




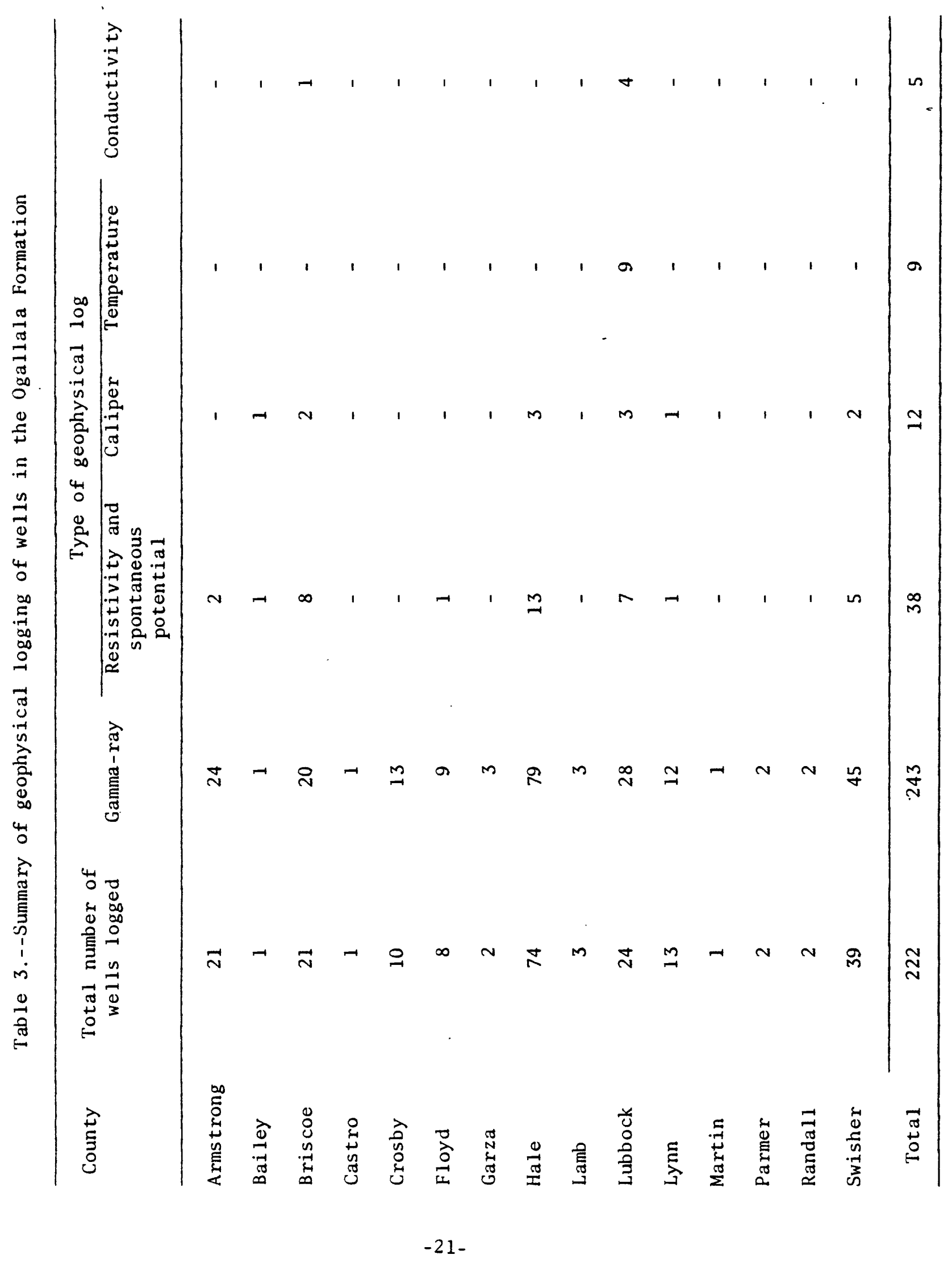


Methods of Measuring Hydraulic Conductivity

The methods used in determining the hydraulic conductivity of the sediments were by laboratory analyses of core samples.

Core samples taken during the test-hole drilling program were analyzed by the U.S. Geological Survey in Denver, Colorado, or by the Texas Water Development Board. The core samples were analyzed for vertical hydraulic conductivity, porosity, specific yield, and grain-size distribution. Some samples from the deeper intervals were analyzed for horizontal hydraulic conductivity. In addition, 10 bag samples were repacked and analyzed for hydraulic conductivity, porosity, specific yield, and grain-size distribution.

The results of laboratory analyses of most of the samples are shown by the graphs on figures 10 and 11 . The minimum vertical hydraulic conductivity of the samples was $5.8 \times 10^{-5} \mathrm{ft} /$ day (feet per day) or $2.05 \times 10^{-8} \mathrm{~cm} / \mathrm{sec}$ (centimeters per second) in test-hole 11-45-2B (Briscoe County) at a depth of 15 to 16 feet. Grain-size analysis for the sample in hole 11-45-2B shows that 45 percent of the sediment is of clay size or finer (less than 4 micrometers) and 75 percent is silt size or less (less than 0.0625 millimeter). 


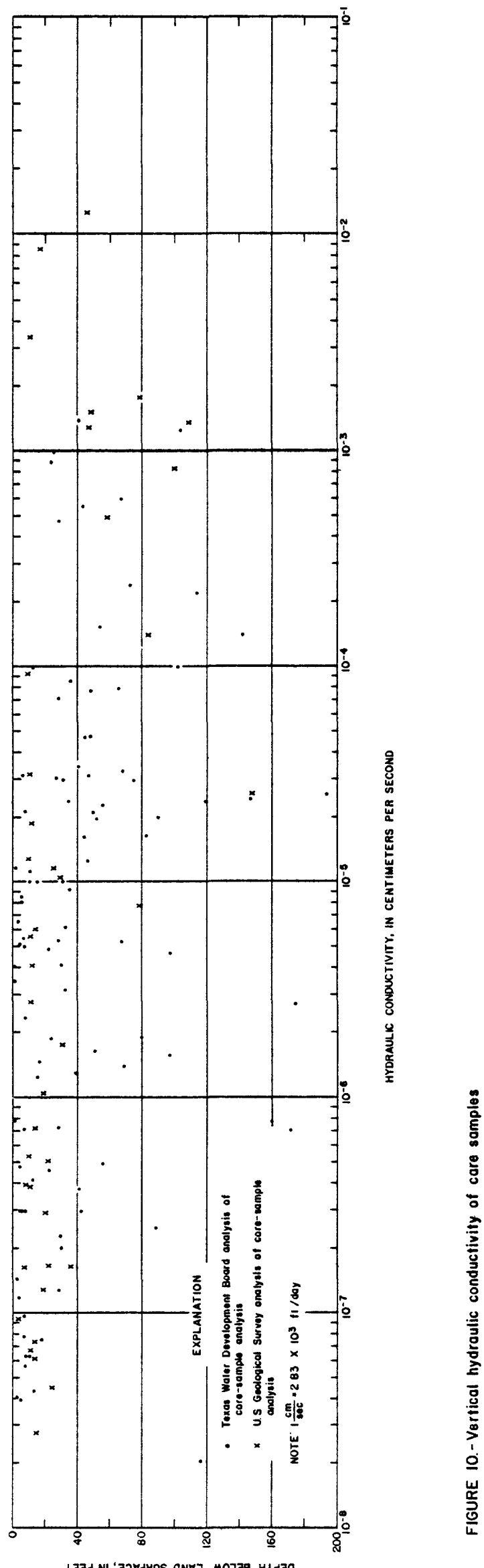

$-23-$ 


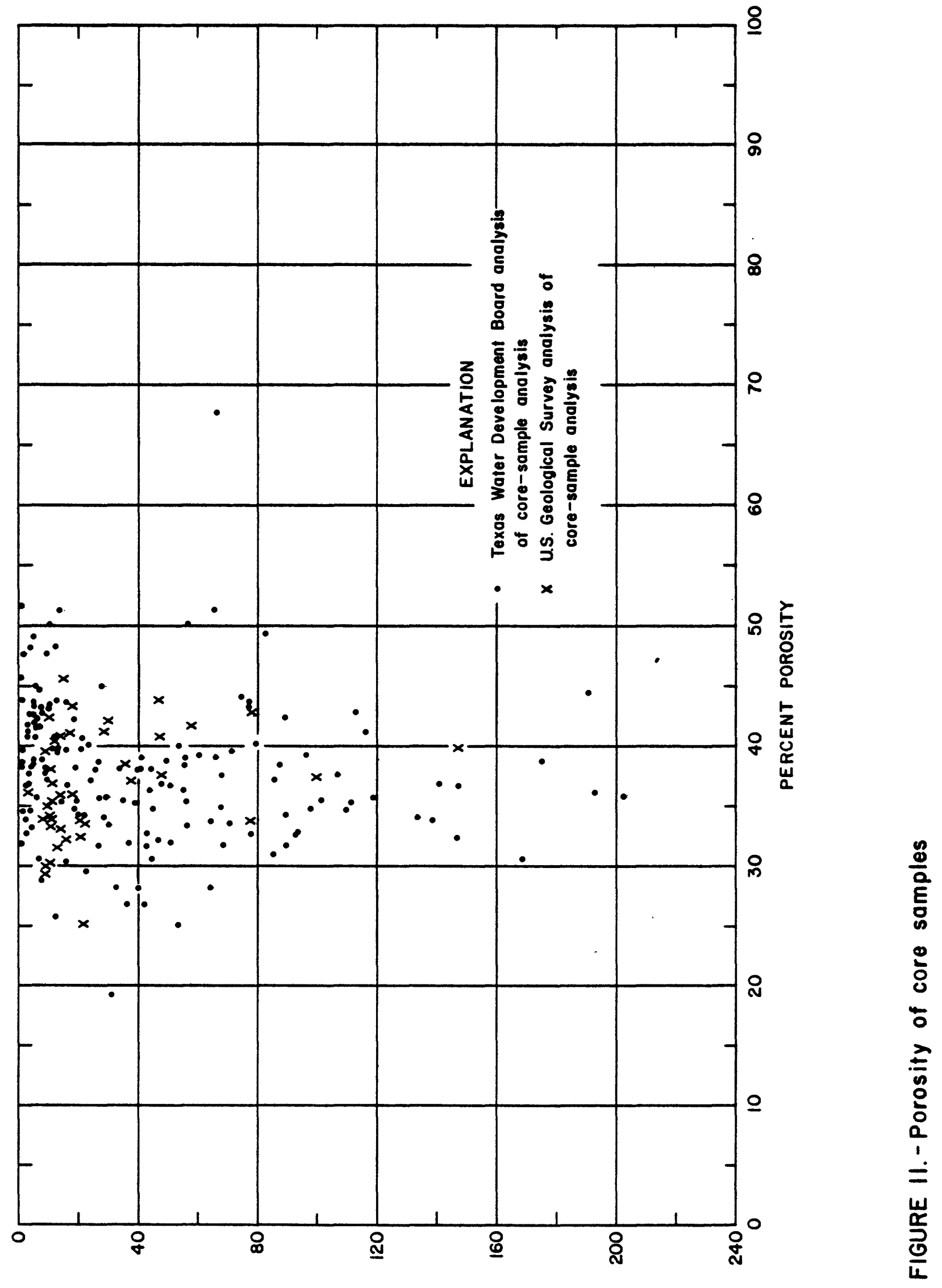

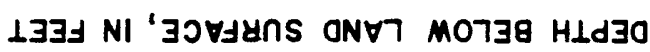


The maximum vertical hydraulic conductivity was $34.5 \mathrm{ft} /$ day $\left(1.22 \times 10^{-2}\right.$ $\mathrm{cm} / \mathrm{sec}$ ) in test-hole 11-60-2A (Hale County) at a depth of 47 to 47.5 feet. In the sample from test-hole 11-60-2A, about 20 percent of the material is of silt size or less, and 75 percent is smaller than fine. sand (less than 0.25 millimeter). Grain-size percentages varied over a wide range, but the average was about 64 percent clay and silt. The porosities of the samples ranged from 25.1 to 45.5 percent.

\section{RESULTS OF THE INVESTIGATION \\ Utility of Drillers' Logs}

Many of the lithologic terms used on drillers' logs are vague or may have several different meanings. For example, some of the descriptions of rock types include such terms as "blue," "red," "break," "dirt," "lakebed," "ledge," "mixture," and "mud and rock" (table 2). Very often, an interval of the formation may be described as "clay, sand, and caliche" or "sand and rock layers."

The term "sand" means little on a driller's log because "sand" by definition, is a particle size, and much of the Ogallala Formation is composed of fine-grained sediments of low hydraulic conductivity. Few drillers use standard particle-size ranges (American Geological Institute, 1960 p. 253), so sediments described as "sand" may be very fine and practically impermeable or may be very coarse and nighly permeable. The term "silt" is seldom used by the drillers, but a high percentage of the Ogallala Formation is composed of silt-size particles. 
A series of commercial drillers' logs, the corresponding geophysical logs, and the interpretations of the geophysical logs are shown on figure 12 .

Good correlation for both lithology and boundaries of the units is shown for logs $A K-11-12-9 A$ and $K Y-11-49-6 A$. Log XT-11-17-2A correlates well witn tine Geological Survey log of the samples collected at the well, but mucn less so with the commercial driller's log. Drillers' logs for wells XT-11-36-5A and JW-23-04-9A also cannot be correlated well with the geophysical logs.

The preparation of good lithologic logs of the Ogallala Formation is difficult because of the complex and rather variable lithology of the deposits. In general, the thicknesses and depths of the different rock types shown on drillers' logs are not closely comparable with those shown by geophysical logs. Differences, many of them amounting to several tens of feet, are attributed to difficulty in interpretation of depth of samples during drilling. Much of the difficulty stems from the fact that the drill commonly has reached a greater depth by the time material from a given depth reacnes the surface. In consequence, the driller's logs commonly indicate a greater thickness of water-bearing sand or gravel than is shown on tine geophysical $\mathrm{log}$. Great care is needed in order to estimate more closely, from drilling characteristics (for example, difficulty of drilling), the depths at which significant changes in material occur.

$$
\begin{aligned}
& -26- \\
& \text { (page } 28 \text { follows) }
\end{aligned}
$$


The completeness and accuracy of the additional information given on drillers' logs (such as location, well-construction data, static water level, yield, and drawdown) differs considerably from one log to another. The casing size, screened or slotted intervals and size, gravel-pack or straightwall designations, pump description, and engine or motor size are incompletely described in many logs. Measurements or estimates of static water levels and pumping levels are commonly included, but in many logs, the time or date of measurement is not given. Yields estimated or based on the pump dischargepipe diameter (a convenient method commonly used) are at best approximate, and may be greatly in error. The specific-capacity values calculated from the given discharge values are therefore approximations also.

In general, the commercial driller's $\log$ is more accurate for the intervals below the water table than for those above it. Greater accuracy below the water table probably reflects closer attention given to the drilling and logging procedures. The base of the Ogallala Formation is usually picked where the lithology changes from sand or sand and gravel to red clay or shale, blue clay or shale, or limestone.

As the usefulness of this information becomes more widely recognized, greater emphasis will be placed on the observation and recording of these data. It should be noted that the wells have usually been drilled to extract water for the least possible cost, and in practice there has been little demand for the accuracy and detail that can be obtained from careful construction of a lithologic log during drilling and from a complete summary of the test data. 


\section{Utility of Computer Analysis of Drillers' Logs}

To determine the utility of computer analysis, data from drillers' logs of wells in Briscoe, Hale, and Swisher Counties were used as input. A sample of the initial computer printout showing a tabulation of the data is shown on figure 13.

After tabulation, the data can be manipulated by using different tablegenerating programs (figure 5). For example, the "total selected sands" routine is a program designed to examine all lithologic data on each $\log$ and to accumulate the thickness of permeable lithologic units such as sand and gravel.

Lithologic rock terms and modifiers used by drillers to indicate good permeability are: Medium-grained sand; medium sand; coarse-grained sand; coarse sand; medium-coarse sand; sand and gravel; grave1; medium-coarse gravel; medium gravel; fine gravel; coarse-grained gravel; river gravel; layers of gravel; small gravel; some gravel; big sand; big gravel; scattered boulders; loose boulders; and some boulders.

In general, the program is written so that the "total selected sands" include all intervals containing gravel, boulders, and sands coarser than medium. A page of computer output, showing the lithology of a log and the accumulated "total selected sands" for the entire log and for the total above the base of the Ogallala, is shown on figure 14 . 
Flgure 13.--Couputer printout giving tabulation of dete from drillers' loge

Genernl card date, colvming 1-26

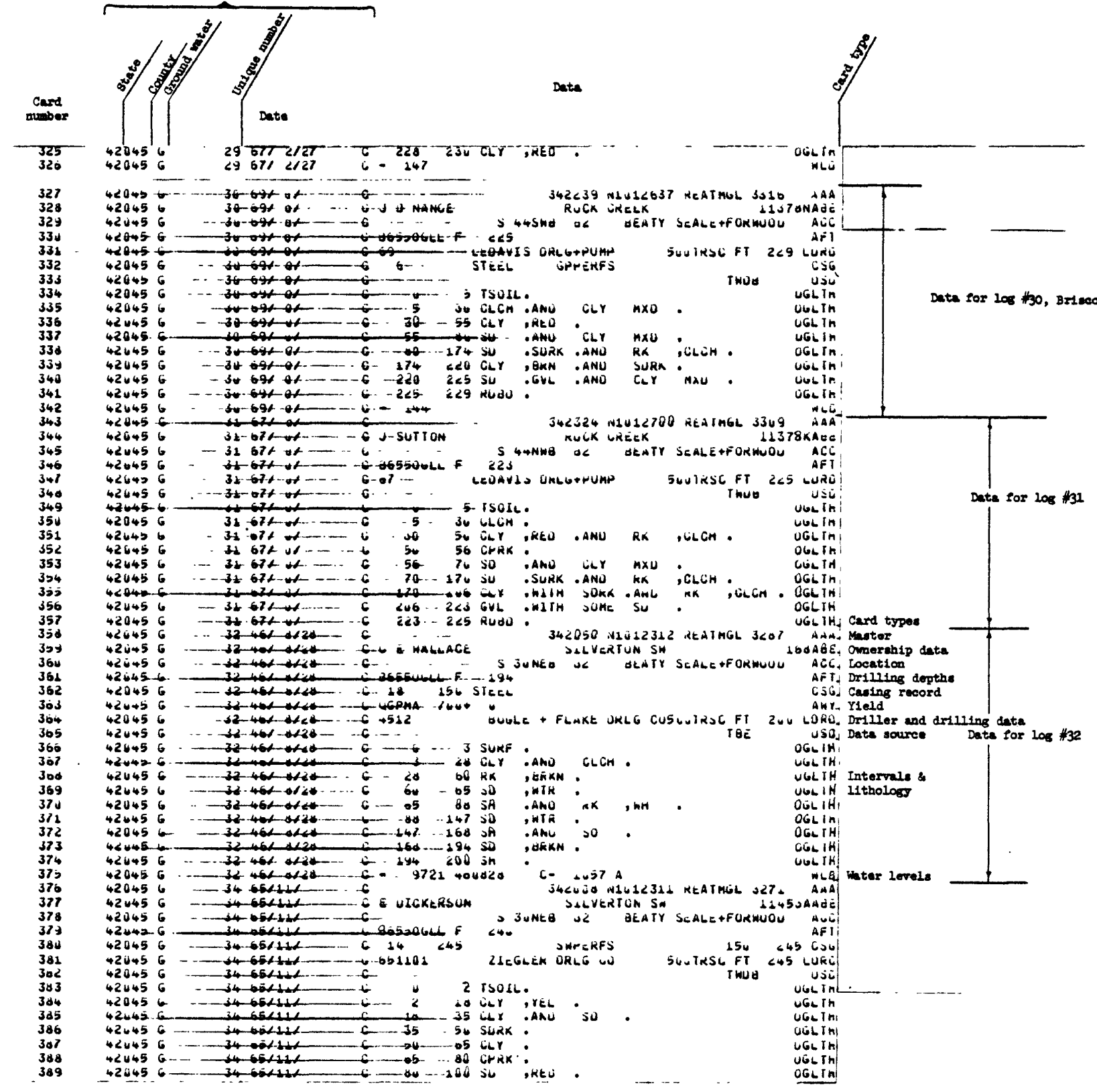




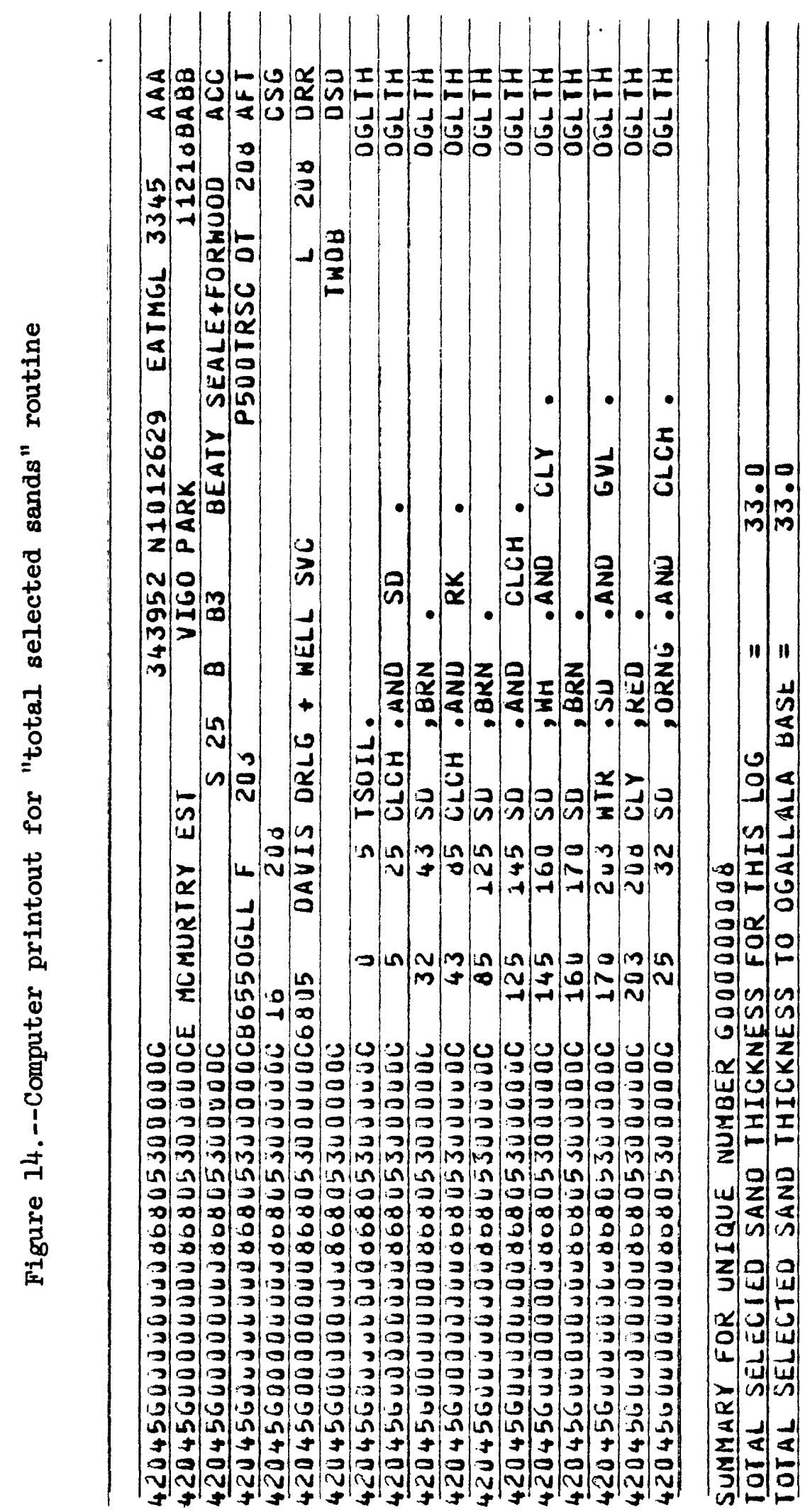


The data selected and accumulated by the table-generating programs are best analyzed by plotting the values on a map. Figure 15 is a Calcom plot of the locations of drillers' logs in southeastern Hale County for sample sets 1 and 2 . The locations, which are represented by squares, are plotted by latitude and longitude. The series of numbers to the left of the point designate the county and the well number. The well number used for this plot, whicn is a "unique number" (figs. $2 \mathrm{a}$ and $2 \mathrm{~b}$ ) assigned by the programmer is not related to the State well number. The numbers to the right show the land-surface elevation. The values given as "0.0" indicate the placement of otiner data that may be desired for that point. Latitude and longitude are shown next to tne intersection symbols (+); however, not all values are shown on tnis sample of the Calcom plot.

This project was terminated before preparation of a computer program to combine the plotting program with the manipulating and accumulating programs, such as "total selected sands." If this had been done, values of "total selected sands" would be printed in place of one of the "0.0" shown on figure 15 .

Other data that could be generated with the plotting routine include tne altitude of the base of the Ogallala Formation and the total thickness of clay, silt, and other similar rock types that occur in the upper 40 and 100 feet of the Ogallala Formation (fig. 16). 


\section{REFERENCE CITED}

American Geological Institute, 1960, Glossary of geology and related sciences, with supplement: American Geol. Institute, Washington, D.C., $397 \mathrm{p}$. 